Cita: Pic, M.; Lavega-Burgués, P.; Muñoz-Arroyave, V.; March-Llanes, J.; Echeverri-Ramos

J.A. (2019). Predictive variables of emotional intensity and motivational orientation in the sports initiation of basketball. Cuadernos de Psicología del Deporte, 19(1), 241-251.

\title{
Predictive variables of emotional intensity and motivational orientation in the sports initiation of basketball
}

\section{Variables predictivas de intensidad emocional y orientación motivacional en la iniciación deportiva del baloncesto}

\section{Variáveis preditivas de intensidade emocional e orientação motivacional na iniciação esportiva do basquete}

\author{
Pic, M. ; Lavega-Burgués, P. ${ }^{2}$; Muñoz-Arroyave, V. ${ }^{2}$; March-Llanes, J. ${ }^{2}$; Echeverri-Ramos, J.A. ${ }^{3}$ \\ ${ }^{1}$ University of La Laguna (Spain) ${ }^{2}$ University of Lleida (Spain) ${ }^{2}$;University of Antioquia (Colombia) ${ }^{3}$
}

\begin{abstract}
The sports initiation of basketball has used exercises and games to improve motor performance, forgetting aspects of maximum importance such as the emotional experience and motivational orientation of players. There were 183 students from public secondary and post-compulsory schools, 103 girls $(56.2 \%)$ and 80 boys $(43.7 \%)$. The validated Games and Emotions Scale questionnaire: GES-II was applied, together with the motivation questionnaire that the students completed after finishing the game situations. Two sessions were held: a) races bouncing a basketball and, b) by teams, passing between teammates a ball that had to be launched over the rival team. Multivariate analyzes were applied, classification trees, specifically the CHAID growth method (Chi-squared Automatic Interaction Detector, in SPSS v.24). The analysis of the predictive variables of emotional intensity indicated that the first explanatory variable was the type of emotion $(p<.001 ; F=1178.369 ; d f 1, d f 2=1833)$. The positive emotions $(\mathrm{e}+)$ $(n=367, M=4.0)$ were more intense $(p<.001)$ than the negative ones (e-) $(n=1468$, mean 1.4). The second predictive variable for both types of emotions was the result. The predictive maps of emotional and motivational experience confirm that the characteristics of the tasks and of the players are two intertwined realities to take into account in integral basketball training.
\end{abstract}

Keywords: Emotion; Motivation; Transfer; Basketball

\section{RESUMEN}

La iniciación deportiva del baloncesto se ha servido de ejercicios y juegos para mejorar la ejecución motriz, olvidando aspectos de máxima importancia como la vivencia emocional y la orientación motivacional de los jugadores. Intervinieron 183 estudiantes de centros públicos de secundaria y postobligatoria, 103 chicas $(56.2 \%)$ y 80 chicos (43.7\%). Se aplicó el cuestionario validado Games and Emotions Scale: GES-II y el cuestionario de motivación que los alumnos cumplimentaron tras finalizar las situaciones de juego. Se realizaron dos sesiones: a) carreras botando

Correspondence to: Miguel Pic, Departament of Specific Didactics (University of La Laguna, Spain). pic.aguilar.90@ull.edu.es 
Pic, M.; Lavega-Burgués, P.; Muñoz-Arroyave, V.; March-Llanes, J.; Echeverri-Ramos, J.A.

un balón de baloncesto y, b) por equipos, pasarse un balón entre compañeros que debía lanzarse sobre el equipo rival. Se aplicaron análisis multivariantes, árboles de clasificación, concretamente se empleó el método de crecimiento CHAID (Chi-squared Automatic Interaction Detector, en SPSS v.24). El análisis de las variables predictivas de la intensidad emocional indicó que la primera variable explicativa fue el tipo de emoción $(p<.001 ; F=1178.369 ; d f 1$, $d f 2=1833)$. Las emociones positivas $(\mathrm{e}+)(n=367, M=4.0)$ fueron más intensas $(p<.001)$ que las negativas (e-) $(n=1468$; mean 1.4). La segunda variable predictiva para ambos tipos de emociones fue el resultado. Los mapas predictivos de la experiencia emocional y motivacional confirman que las características de las tareas y de los jugadores son dos realidades entrelazadas a considerar en el entrenamiento integral del baloncesto.

Palabras clave: Emoción; Motivación; Transferencia; Baloncesto.

\section{RESUMO}

A iniciação esportiva do basquete vem utilizando jogos e exercícios para o desenvolvimento da performance técnica, esquecendo aspectos fundamentais como a experiência emocional e a orientação motivacional dos jogadores. Participaram 183 estudantes de escolas públicas de ensino médio, sendo 103 mulheres (56.2\%) e 80 homens (43.7\%). Aplicou-se o questionário validado Games and Emotion Scale: GES-II e o questionário de motivação, que foi preenchido após a finalização das situação de jogo. Foram realizadas duas sessões: a) corridas com dribles com a bola de basquete e, b) jogo por equipes, passando uma bola entre seus companheiros de time que deviam lança-la sobre a equipe rival, tentando eliminá-los. Foram aplicadas análises multivariáveis, árvores de classificação, e aplicado o método de crescimento CHAID (Chi-squared Automatic Interaction Detector, SPSS v.24). A análise das variáveis preditivas da intensidade emocional indicou que a primeira variável explicativa foi o tipo de emoção $(p<.001 ; \mathrm{F}=1178.369 ; d f 1, d f 2=1833)$. As emoções positivas $(\mathrm{e}+)(\mathrm{n}=367, \mathrm{M} 4.0)$ foram mais intensas $(p$ $<.001)$ que as negativas (e-) $(\mathrm{n}=1468 ; \mathrm{M} 1.4)$. A segunda variável preditiva para ambos tipos de emoções foi o resultado. Os mapas preditivos da experiência emocional e motivacional confirmam que as características das tarefas e dos jogadores são duas realidades entrelaçadas para o treinamento integral do basquete.

Palavras chave: Emoção; Motivação; Transferência; Basquete. 


\section{Predictive variables of psychological orientation in the sports initiation of basketball}

\section{INTRODUCTION}

Pedagogical arguments are needed to guide the proposals for sports initiation. The initiation to basketball is not an exception, being necessary, above all, proposals that specify the complex (Araújo, Davids, \& Hristovski, 2006) process of teachinglearning within the physical education class (PE). The practice of basketball with an educational focus implies a constant decisional adjustment for the teacher of the area in the adaptation of tasks or with the resolution of unexpected events of a diverse nature. It is not the same to speak aloud individually, than to discuss a conflictive topic with several people in favor and against in differentiated groups. Moving the case and in terms of motor action (Parlebas, 2001) in a task of psychomotor (individual, without interaction with other players) involvement participation is the stereotyped reproduction of a motor action more or less known, while when the task is cooperation-opposition (sociomotor), motor actions respond to a constant decision-making (Musculus, Raab, Belling, \& Lobinger, 2018) in situations of play that vary due to the uncertainty generated by interaction with peers and adversaries.

Different experiences have supported that interpersonal education in the field of motor game is a fact. School coexistence (Sáez, Lavega, Mateu, \& Rovira, 2014) is not a minor objective within the school institution. Students must be able to live in society at the end of the academic period. The game is an unbeatable resource for motor education. Its plasticity allows the adaptation of students to an original micro world. The playful preferences between girls and boys, the previous experience or the result of the game could be the cause of modifying and intensifying the positive and negative emotions (Lazarus, 2000) of the students. Therefore, we start from the assumption that identifying causes is a priority pedagogical need. Succeeding with pedagogical progressions by adjusting the process to the students should be based on empirical evidence and not on repetitive improvisation or inertia. How can a pedagogical progression of basketball initiation (Serna et al., 2017; González-Espinosa, Ibáñez, \& Feu, 2017) be justified without considering the gender (Gorely, Holroyd, \& Kirk, 2003) of the students or the type of motor interaction of the task (Ibáñez, Feu, \& Cañadas, 2016)? The teacher must assume that educational quality depends to a large extent on the validity of his or her arguments. To know the answers of the real protagonists in our physical education classes is to have feedback with which to enrich and improve the educational process. The study of predictive variables for sports initiation in basketball would increase the knowledge on which to base the reason for our pedagogical decisions.

The transfer of practical knowledge between tasks is a powerful methodological resource that can help make learning from any motor practice affordable. Basketball is a shared space cooperation-opposition sport, in which 10 players dispute the possession of a ball seeking to obtain baskets to overcome the opponent. The sports initiation of basketball has used exercises and games to improve motor performance, forgetting aspects of maximum importance such as the emotional experience and motivational orientation of players (Lavega, Alonso, Etxebeste, Lagardera, \& March, 2014; Ntoumanis, 2005). Scientific evidence confirms that individualizing training favors the emotional and motivational well-being transferable to the game action. To promote this individualizing wellbeing is necessary to consider the characteristics of the motor tasks and also the traits of the participants.

Knowing the students' motivational profile can show details that would help the teacher in their daily work. Originally, a distinction was made between learning goals and performance goals (Dweck \& Leggett, 1988). Afterwards, it was a three-dimensional perspective (Elliot, 1999) that addressed trends in the approach to performance, subsequently enriched by the inclusion of avoidance tendencies and learning goals, thus enabling a model composed of four dimensions. At present, the theory of achievement goals is one of the most relevant lines of research for academic motivation (Fernández-Arata, 2008). From the point of view of sports initiation, Mastery and Social comparison would be among the goal categories of known achievement goals. While focusing on the process and hard work to increase skills would correspond with excellence (mastery), social orientation would be identified rather with demonstrating the value of comparing with others. In a PE context, the competence perceived by the students correctly anticipated the goals of approachmastery and approximation-performance (González- 
Pic, M.; Lavega-Burgués, P.; Muñoz-Arroyave, V.; March-Llanes, J.; Echeverri-Ramos, J.A.

Cutre, Sicilia, \& Moreno, 2008). With basketball players (Sáenz-López, Mateos, Almagro, \& Conde, 2017)it was justified that athletes value effort (mastery) over performance, in line with previous literature (Castillo, Duda, Álvarez, Mercé, \& Balaguer, 2011).

The motivational profile must necessarily be translated into the decisions that the players must adopt when they find themselves in a compromised situation. In the design of the task, the teacher finds a tool to adapt the class to specific profiles. Each task arises from a family of motor interactions (Parlebas, 2001), which reveals an intrinsic decisional complexity (Araújo, Teques, Hernández-Mendo, Reigal, \& Anguera, 2016; Musculus, Raab, Belling, \& Lobinger, 2018; Pic, Navarro-Adelantado, \& Jonsson, 2018). Thus, the reproduction of a technical action without adversaries or partners, does not give decisional complexity to a task that requires only the reproduction of a previous action model (e.g., free throw) while from the moment the ball is in action in a basketball game (Courel-Ibáñez, Suárez-Cadenas, Ortega, \& Cárdenas, 2018), the counter decisions (rivals) or even communicative interferences (noise) that hinder this relational process of positive sign (Heider, 1946) between peers or negative between rivals.

At the same time, sexual stereotypes (Chalabaev, Sarrazin, Fontayne, Boiché, \& Clément-Guillotin, 2013) are not excluded from any human or motor relationship, even pointing to an anachronistic Olympic motto (Pic, 2018). Therefore, the classroom becomes a laboratory of social asymmetries. The teacher must assume the promotion of a shared physical education, being able to allude also to the result of the game as an indicator of the more or less satisfactory experience of the players. The previous experience of the students (Mellalieu, Hanton, \& O'Brien, 2004; Prieto, 2017) can also modify the protagonism that the students show. Thus, a teaching planning must attend to this type of premises to pedagogically optimize the daily practice. From a motor perspective, the boys performed the most satisfactory experiences in opposition tasks, while the girls experienced very satisfactory experiences in cooperation tasks (Lavega, Lagardera, March, Rovira,
\& Aráujo, 2014; Muñoz, Lavega, Serna, Sáez de Ocáriz, \& March, 2017).

Having evidence that helps to understand the emotions generated in boys and girls by the teaching practices in the practical application can be an advance. Although the increase in emotional intensity caused by cooperative games was more linked to girls, opposition games, on the other hand, were more preferred by boys (Etxebeste, 2012). It has been recently confirmed that children are more likely to show negative experiences than positive ones (Lavega, Sáez de Ocáriz, Lagardera, March \& Puig, 2017). Therefore, the needs of students in an educational context should not be understood as a homogeneous whole, but could be subject to or depend on the sports curriculum of the player, gender or motor domain used in practice, among other variables. It is necessary to unravel which variables, together with their relationships, to know and complete this interpretive circle in order to improve the initiation of basketball within the physical education class.

Based on everything commented above, the objective of this research was to determine the predictive capacity of emotional intensity and the motivational orientation (social orientation or mastery) of variables associated with the tasks of the game (type of relational task: psychomotor and cooperationopposition game, result of the task: win-lose) and other factors related to the participants (types of emotion experienced: positive or negative); gender (male, female) and sports history (with or without sports background) that is, if they had any experience in sports competition.

\section{METHOD}

\section{Participants}

The study was done with $183(M=14.61, S D=1.84)$ students from public secondary and post-compulsory schools, 103 girls (56.2\%) and 80 boys (43.7\%). Less than half of the students had competitive experience. Express approval was obtained from the ethics committee of the University of Lleida to apply the protocols in different places of the Spanish geography. As the students were minors, in all cases there was express authorization (signed) from the tutors, allowing them to be part of the experience. 


\section{Predictive variables of psychological orientation in the sports initiation of basketball}

\section{Instruments and Procedure}

After finishing each game the students completed the validated Games and Emotions Scale questionnaire: GES-II (Lavega-Burgués, March-Llanes, \& MoyaHigueras, 2018). This scale was applied, together with the motivation questionnaire (Ntoumanis, 2005). In both questionnaires, the responses of the individuals fluctuated on a scale of 7 possible responses from the lower value ' 1 ' to ' 7 ', totally aligned with the maximum fulfillment of the item. The positive emotion was joy while the negative emotions were sadness, fear, anger and rejection. Both questionnaires were applied in spanish languge, with the motivation questionnaire translated by a specialist.

Following previous experiences (Larraz, 2004; Salvador, 2018) that organized educational content based on praxiological indicators, individual participation would have an importance linked to motor reproduction, while a game of cooperationopposition would have more relational harmony with basketball. In this studio, two sessions were held: a) races bouncing a basketball and, b) by teams, passing between teammates a ball that had to be launched over the rival team. This procedure was carried out within the PE class schedule. One session was dedicated for each game. In total, approximately $15-20$ ' of recording per game and another $15^{\prime}$ to complete the questionnaires were required. The games of the study were, a) The psychomotor game, which consisted of 'races with victory', the participants were placed in even numbers across the basketball court being paired the first player of row one with the first of row two and so on. In front of each row there was a cone 10 meters away. The idea was to make a round-the-clock speed race by bouncing the basketball, the winner being the player who arrived earlier. There were three races varying the dominant hand and alternating dominant-hand non-dominant hand.

The second game has different denominations, b) 'balón prisionero' (Parlebas, 2001) or 'balón quemado' or (close rules to dodgeball game) consisted of getting accurate shots against the opponent so that these players were directed to the prison area. To do this, the space was divided into two symmetrical fields separated by a central line that acted as a border. Two background lines, diametrically opposed to each other, marked two prisons. Two teams with the same number of players (8-15 players) were throwing a ball and the team which turned all the rival players into prisoners was the winner.

The teachers of the class groups were commissioned to implement the motor games. In order to homogenize and facilitate the explanation of the games, images of the same games were recorded, coming from other game contexts in order to solve teachers' possible doubts. These images were sent to the teachers about two months before the development of the experience. Before the game was played from beginning to end, the teachers were always recommended to use 2-3 minutes to clarify the questions or doubts of the students.

\section{Data analysis}

Multivariate analyzes were applied, classification trees, specifically the CHAID growth method (Chisquared Automatic Interaction Detector, in SPSS v.24), generating different trees by applying: a) Pearson's Chi square values, b ) cross-validation, c) range of interactions $(n \geq 100, n \geq 50)$ and d) statistical significance $(p<.05)$, for the establishment of the model and thus predict the variables emotional intensity and motivational profile (orientation towards mastery and social). The predictive variables were: a) type of emotion (positive, negative), b) type of game: motor relationship (cooperation-opposition, psychomotor), c) type of game: result (win, lose), d) gender (girl or boy), e) sports history (with or without a history in competition).

\section{RESULTS}

The first explanatory variable of emotional intensity was the emotion type $(p<.001 ; F=1178.369 ; d f 1, d f 2$ $=1833)$. The positive emotions $(\mathrm{e}+)(n=367, M=4.0)$ were more intense $(p<.001)$ than the negative ones (e-) $(n=1468, M=1.4)$. The second predictive variable for both types of emotions was the result: losing recorded more intense values of $\mathrm{e}+(p<.001)(n$ $=676, M=1.5)$ with respect to winning $(n=792, M=$ 1.2). In the opposite direction, the e- were superior to winning $(n=198 ; M=4.5)$ with respect to losing $(n=$ $169 ; M=3.4)$. In the e+ the third predictive variable was recorded only in the loss result and corresponded to the type of game. The highest emotional intensity ( $p$ 
Pic, M.; Lavega-Burgués, P.; Muñoz-Arroyave, V.; March-Llanes, J.; Echeverri-Ramos, J.A.

$<.002$ ) was generated by the cooperation-opposition ( $n$ $=90, M=3.8)$ versus the psychomotor games, node 7 $(n=79, M=2.9)$. For the e-, the third predictive variable was obtained in the winning result and corresponded to the type of sports history ( $\mathrm{SH})$. The students with $\mathrm{SH}$ experienced more intense e- $(p$ $<.003)$ when winning $(n=352, M=1.3)$ than the students without $\mathrm{SH}(n=440, M=1.1)$.

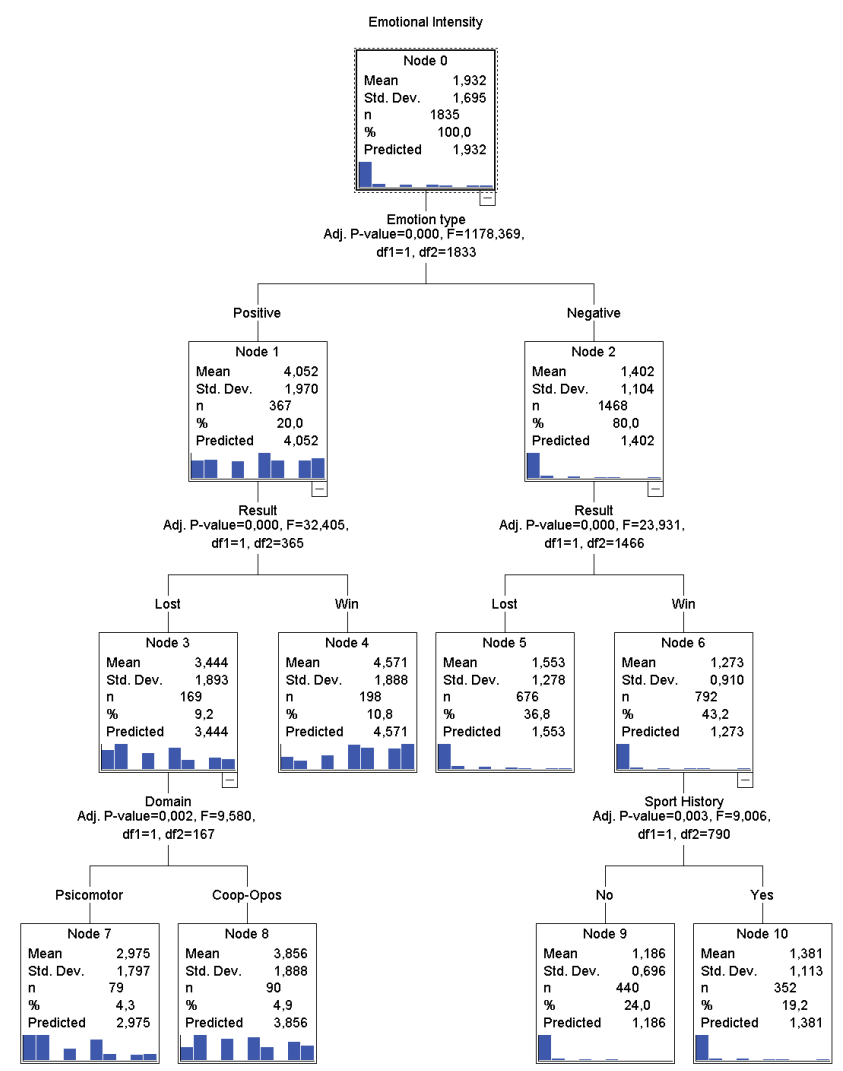

Figure 1. Tree of predictive variables (IV): emotion type (positive/negative), gender (girl/boy), result (win/lost), domain (psychomotor/coop-opos), sport history (no/yes), taking into account over Emotional Intensity (DV).

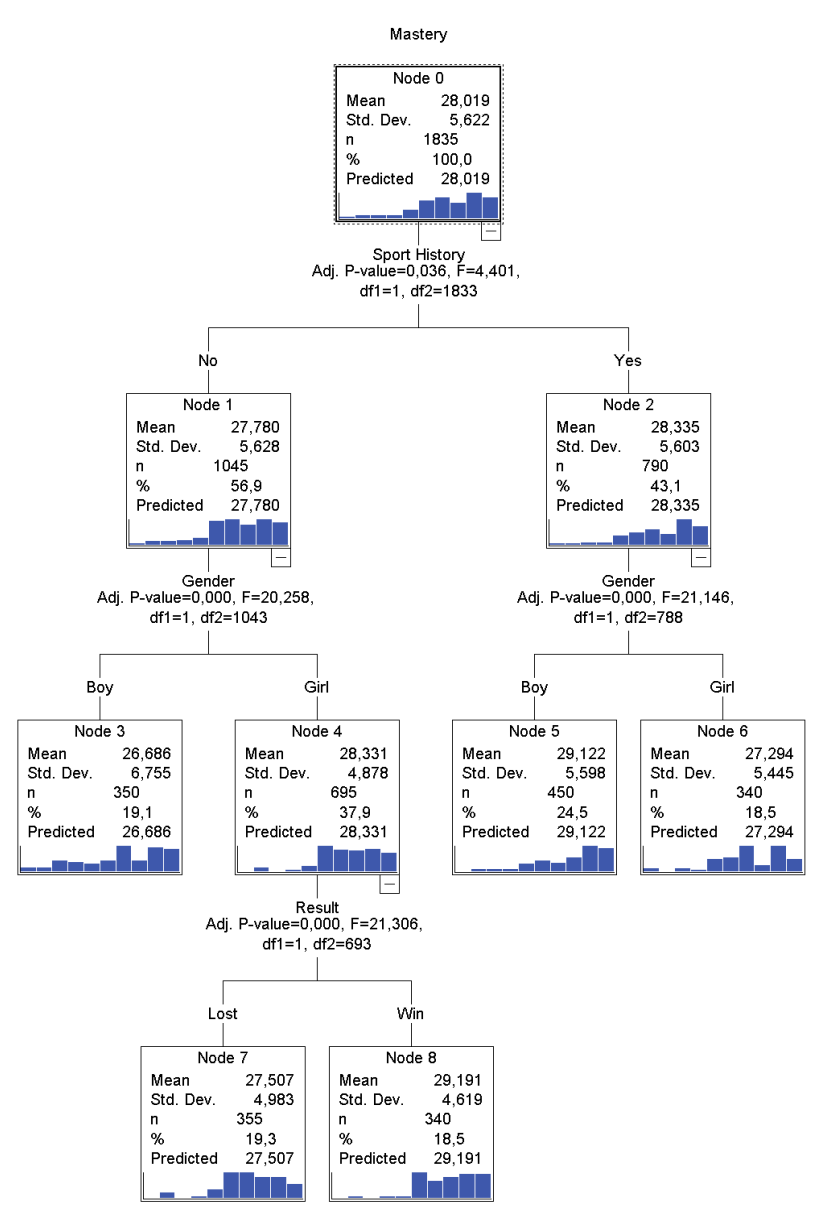

Figure 2. Tree of predictive variables (IV): emotion type (positive/negative), gender (girl/boy), result (win/lost), domain (psychomotor/coop-opos), sport history (no/yes), taking into account over Mastery (DV).

In parallel, with regard to motivational orientation (social or mastery), three predictive variables were identified. The first one for both orientations was sports history ( $\mathrm{SH})$. Players with $\mathrm{SH}$ experienced more intense values $(p<.001)$ than students without a sports background. Among the SH players, the boys had higher values $(p<.001)$ than the girls. On the other hand, this result was reversed $(p<.001)$ among students without $\mathrm{SH}$. The third variable for players without $\mathrm{SH}$, was the result; the girls without $\mathrm{SH}$ when losing obtained more intense values $(p<.001)$ of orientation of mastery and less intense $(p<.001)$ of social orientation. For boys, only when they lost a 


\section{Predictive variables of psychological orientation in the sports initiation of basketball}

greater intensity of social orientation was observed ( $p$ $<.001)$.

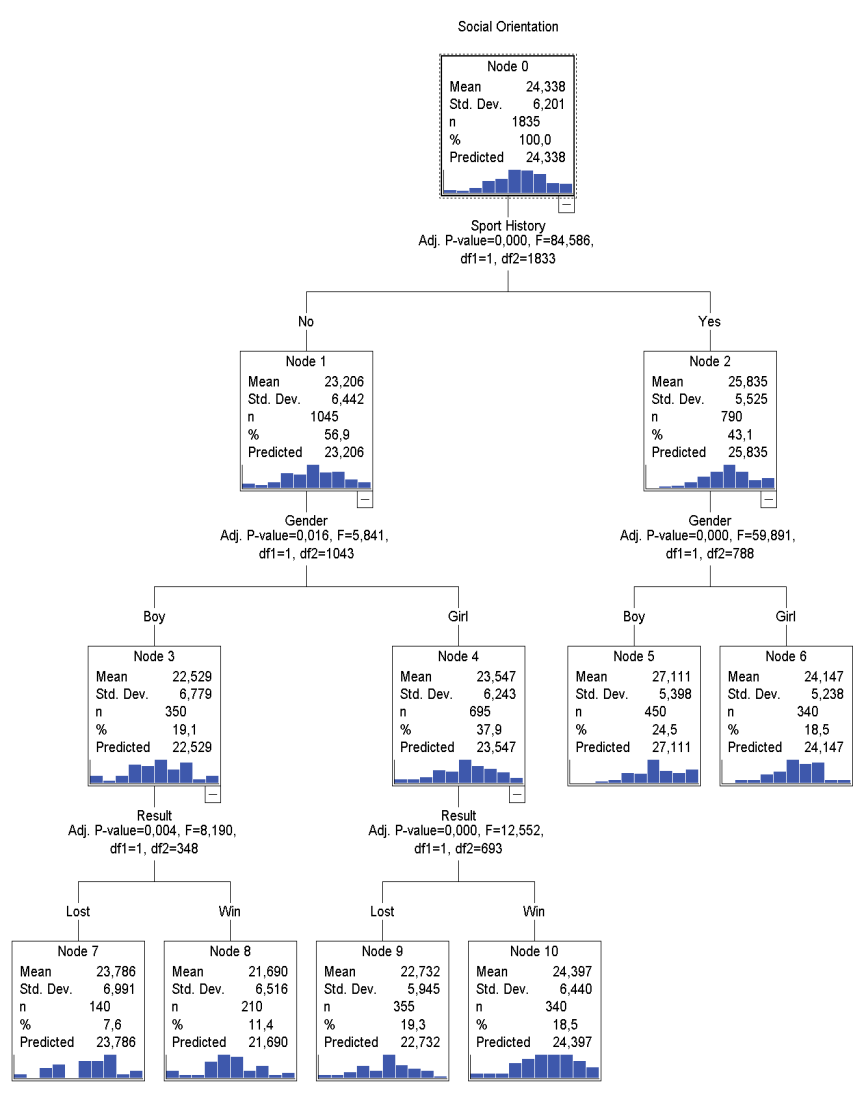

Figure 3. Tree of predictive variables (IV): emotion type (positive/negative), gender (girl/boy), result (win/lost), domain (psychomotor/coop-opos), sport history (no/yes), taking into account over Social Orientation (DV).

The differences between figures 2-3 are scarce. Although it should be noted that the average values of Mastery (28) exceeded Social Orientation (22.3) from their respective origin nodes. On the other hand, from the result variable obtained by the boys without sports history $(p<0.04)$ (Figure 3 ), it emerged when losing the node $7(n=140 ; 23.7)$ and when winning the node $8(n=210 ; 21.69)$, nonexistent in the predictive tree that took Mastery as dependent variable.

\section{DISCUSSION}

The objective of this research was to determine the predictive capacity of emotional intensity and the motivational orientation of variables associated with the tasks of the game and other factors related to the types of emotion experienced by participants: sex and sports history.

This research scientifically confirms that the game mostly triggers emotional and motivational wellbeing. The priority objective was fulfilled when revealing that both the emotions expressed by the students and the profile of our students were unequally distributed, generating differentiated predictive models based on the interaction of variables. Basketball coaches should know that well-being depends mainly on the characteristics of the intervention on the task (result of the intervention, and whether it is a collective or individual game). In parallel, the orientation of the motivational profile towards the pursuit of mastery (perfection in the intervention) or the social relationship depends mainly on gender, history, and finally whether the participants win or lose. These effects must be known by the teacher, not only to reflect more clearly about a better methodological adequacy, but also to reorient the task of initiation to basketball based on empirical evidence.

Attending exclusively to 'technical' actions, for the analysis of a practice can be excessive, especially if the concept of motor interaction is not taken into account (Parlebas, 2001). The present study was based on a purely relational procedure that allowed a motor transfer in this same sense, without sacrificing the specificity of basketball. While in the psychomotor game, the reproduction of motor actions without relational interference was valued, in the game of cooperation-opposition were the skills to synchronize the motor interactions with the peers against rivals, among other essential actions of basketball, to obtain victory. Thus, it could be stated that to understand the emotional intensity (Figure 1) it was necessary to resort to the domain of motor action (node7 and node8), obtaining greater emotional intensity under the domain of cooperation-opposition.

The emotional intensity could be equivalent in girls and boys since it did not appear in the box of predictive variables (Figure 1). It was known that boys preferred to intensify rivalry over girls, and girls preferred to cooperate (Lavega, Alonso et al., 2014; Muñoz et al., 2017). Thus, in this study, the scores of the cooperation-opposition dimension could overcome the psychomotor one because both girls and boys found their relational preference in it. 
Pic, M.; Lavega-Burgués, P.; Muñoz-Arroyave, V.; March-Llanes, J.; Echeverri-Ramos, J.A.

Perhaps concluding that cooperation-opposition is the most indicated domain in sports initiation supposes a daring thought, but this idea can be better assimilated when knowing that basketball is a sport of cooperation-opposition and, in this sense, a possible preferential domain to optimize the experience of greater emotional intensity (Jaqueira, Lavega, Lagardera, Aráujo, \& Rodrigues, 2014). Along these lines, achieving a motor and emotional education (Bisquerra, 2000) is to address an interpersonal education (Durán, Lavega, Salas, Tamarit, \& Invernó, 2014) showing that the greatest emotional intensity was aligned with positive emotions when winning and with negative emotions when losing.

Without leaving emotional intensity behind, the results encourage a previous exploration to know the sport history of the students, given that the players with sports history experienced with more intensity the negative emotions even when winning, which could be contradictory (Node9 and Node10). That is to say, this could be due to the fact that the students with the most competitive experience are constantly looking for victory, generating negative emotions. Thus, it would no longer be a question of redirecting the basketball (Courel-Ibáñez, Suárez-Cadenas, Ortega, \& Cárdenas, 2018), initiation class solely because of the students' sporting experience, but also because of the emotional experience it provokes.

Between the motivational profile (Elliot, 1999; Fernández-Arata, 2008) of mastery (Figure2) and social orientation (Figure 3) an almost perfect symmetry was reproduced according to the different nodes of the predictive model. The higher average values of Mastery versus Social Orientation, that is to say Mastery or the capacity of perception of excellence played a more important role than social orientation in the practice. The motivational profile of the students reveals that the sports record must be known, as well as the gender, in the initiation to basketball. Some experiences have helped to specify a gender profile (Kivikangas, Kätsyri, Järvelä, \& Ravaja, 2014), with numerous contributions from the motor game (Lagardera \& Lavega, 2011), confirming that boys experienced mostly negative emotions with greater intensity (Muñoz et al., 2017; Lavega et al., 2017) while girls experimented more intensely positive emotions (Lavega, Lagardera et al., 2014). A study that started from games of cooperation, opposition, psychomotor and cooperation-opposition concluded without finding emotional differences among students because of gender (Lavega, Filella, Lagardera, Mateu, \& Ochoa, 2013), in line with the study we present in relation to emotions. However, some arguments were given that help to consider different motivational profiles with gender as the protagonist. Therefore, more research is needed to help uncover the acceptance or refutation of characterization based on gender (Gorely, Holroyd, \& Kirk, 2003) and, what is more essential, its translation into a pedagogical design.

On the other hand, regardless of the sporting history, the motivational profile (González-Cutre et al., 2008) of girls and boys is specific, and it has been previously shown although just on an emotional level (Sáez de Ocáriz, Ureña, Lavega, \& Serna, 2013). Among the students with no sports record (Figure 3), the boys obtained lower values when they won than when losing, while in girls it happened the other way around. In other words, if girls win they get high points when compared with others (Social), and boys increase scores when losing. In parallel, also in Mastery girls scored high again when winning (Sáenz-López et al., 2017), which might invalidate the previous argument, since high values in Mastery means giving importance to the process and comparison with the results themselves. Girls may be able to unify both perspectives, while boys lack that internal requirement but show the external one.

It is complex (Araújo, Davids, \& Hristovski, 2006) to understand a coherent pedagogical discourse without knowing in depth the causes that would explain the motivations of the students and the emotions that emerge before the different sports initiation practices in basketball (Reina, Mancha, Feu, \& Ibáñez, 2017). The transfer of knowledge is a fundamental element, that cannot be ignored from the pedagogical point of view in order to create healthy habits of motor practice, and also to make the students reflect on the requirements that each task demands to be successful. This is undoubtedly one of the dimensions of education quality as it is knowing the profile of the students who attend class. 


\section{Predictive variables of psychological orientation in the sports initiation of basketball}

\section{PRATICAL APPLICATIONS}

Among the applications of the study, all teachers should know their students' profiles through similar experiences. Sometimes, teachers make pedagogical progressions about an abstraction that is far from the true profile and needs of the students, thus increasing the possible pedagogical mismatch between the students' needs, the pedagogical planning and the court. Having this knowledge holds an incalculable value to undertake more accurate pedagogical adjustments on the complexity involved in any teaching-learning process. Motor-type interactions are constructions that rest on internal (Parlebas, 2001) and situational logic. It is thus possible for the teacher to use these tools provided by motor action in their design procedures to perform tasks that respond to specific objectives. Breaking communication ice between students with difficulties to transmit during the first days of class requires specialists in interpersonal education. This relevance of the teacher's sensitivity to accommodate different motivational or emotional profiles before planning must be found among teaching attentions. Therefore, individualizing the learning of our students is among the most relevant applications of this work, to do so addressing the students profiles from different dimensional approaches can be key.

The limitations of the study go through evaluating motor behavior in basketball initiation. It would be advisable that the motivation questionnaire were validated to the Spanish language. Future research should consider including an observational methodology through which to address the relationship between players in the form of roles, as well as having descriptive accounts of the players themselves. The use of mixed methods (Anguera \& Hernández-Mendo, 2014; Anguera \& HernándezMendo, 2016) could combine different visions, as well as include predictive analysis including the temporal dimension in the search for invisible T-Patterns (Pic, 2017). On the other hand, specifying not only the type of emotion but also revealing what concrete emotion was aroused could open new interpretations as well as generate new approaches.

\section{CONCLUSIONS}

The predictive maps of emotional and motivational experience confirm that the characteristics of the tasks and of the players are two intertwined realities to consider in integral basketball training (Serna et al., 2017). It is advisable to know in depth the processes that each motor task triggers, from the point of view of motor or decisional responses as well as emotional and motivational levels. Likewise, it is necessary to recognize the subjective characteristics of the players to guarantee an individualized training that originates the maximum transfer (Parlebas, 2001) from the exercises to real game situations.

\section{FUNDING}

We gratefully acknowledge the support to the National Institute of Physical Education of Catalonia (INEFCLleida) through the projects PARINEFC2016_005 and 2015 PINEF 00002

\section{REFERENCES}

1. Anguera, M. T., \& Hernández-Mendo, A. (2014). Metodología observacional y psicología del deporte. Estado de la cuestión. Revista de Psicología del Deporte, 23(1), 103-109.

2. Anguera, M. T., \& Hernández-Mendo, A. (2016). Avances en estudios observacionales de Ciencias del Deporte desde los mixed methods. Cuadernos de Psicología del deporte, 16(1), 17-30.

3. Araújo, D., Davids, K., \& Hristovski, R. (2006). The ecological dynamics of decision making in sport. Psychology of Sport and Exercise, 7, 653-676. doi: 10.1016/j.psychsport.2006.07.002

4. Araújo, D., Teques, P., Hernández-Mendo, A., Reigal, R.E., \& Anguera, M.T. (2016). La toma de decisión, ¿es una conducta observable?: Discusión sobre diferentes perspectivas teóricas utilizadas en el estudio del rendimiento deportivo. Cuadernos de Psicología del Deporte, 16(1), 183-196.

5. Bisquerra, R. (2000). Educación emocional y bienestar. Barcelona: Praxis.

6. Castillo, I., Duda, J. L., Álvarez, M. S., Mercé, J., \& Balaguer, I. (2011). Clima motivacional, metas de logro de aproximación y evitación y bienestar en futbolistas cadetes. Revista de Psicología del Deporte, 20(1), 149-164.

7. Chalabaev, A., Sarrazin, P., Fontayne, P., Boiché, 
J., \& Clément-Guillotin, C. (2013). The influence of sex stereotypes and gender roles on participation and performance in sport and exercise: Review and future directions. Psychology of Sport and Exercise, 14(2), 136-144.

https://doi.org/10.1016/j.psychsport.2012.10.005

8. Courel-Ibáñez, J., Suárez-Cadenas, E., Ortega, E., \& Cárdenas, D. (2018). Training Proposal for the Inside Game in Basketball. Apunts. Educació Física $i$ Esports 133, 98-115. doi: http://dx.doi.org/10.5672/apunts.2014-

0983.es.(2018/3).133.07

9. Durán, C., Lavega, P., Salas, C., Tamarit, M., \& Invernó, J. (2015). Educación Física emocional en adolescentes. Identificación de variables predictivas de la vivencia emocional. Cultura, Ciencia y Deporte (CCD), 10(28), 5-18. doi.org/10.5672/apunts.20140983.cat.(2014/3).117.02

10. Dweck, C.S., \& Legget, E. L. (1988). A Socialcognitive approach to motivation and personality. Psychology Review, 95(2), 256-273.

11. Elliot, A. J. (1999). Approach and avoidance motivation and achievement goals. Educational Psychologist, $\quad 34, \quad 169-189$. doi.org/10.1207/s15326985ep3403_3

12. Etxebeste, J. (2012). À cloche-pied. Les jeux sportifs traditionnels et la socialisation des enfants basques. Sarrebruck: Editions universitaires européennes.

13. Fernández-Arata, J. M. (2008). Desempeño docente y su relación con orientación a la meta, estrategias de aprendizaje y autoeficacia: un estudio con maestros de primaria de Lima, Perú. Universitas Psychologica, 7(2), 385-401.

14. González-Cutre D., Sicilia A., \& Moreno, J. A. (2008). Modelo cognitivo-social de la motivación de logro en educación física. Psicothema, 20(4), 642651.

15. González-Espinosa, S., Ibáñez, S. J., \& Feu, S. (2017). Diseño de dos programas de enseñanza del baloncesto basados en métodos de enseñanzaaprendizaje diferentes. E-balonmano.com: Revista de Ciencias del Deporte, 13(2), 131-152. http://www.ebalonmano.com/ojs/index.php/revista/index

16. Gorely, T., Holroyd, R., \& Kirk, D.
(2003). Muscularity, the Habitus and the Social Construction of Gender: Towards a gender-relevant physical education. British Journal of Sociology of Education, 24(4), 429448. doi:10.1080/01425690301923

17. Heider F. (1946). Attitudes and cognitive organization. The Journal of Psychology, 21, 107112. 10.1080/00223980.1946.9917275

18. Ibáñez, S. J.; Feu, S.; Cañadas, M. (2016). Sistema integral para el análisis de las tareas de entrenamiento, SIATE, en deportes de invasión. E-balonmano.com: Revista de Ciencias del Deporte, 12(1), 3-30. http://www.e-

balonmano.com/ojs/index.php/revista/index

19. IBM Corp. (2016). IBM SPSS Statistics for Windows, Version 24.0. Armonk, NY: IBM Corp

20. Jaqueira, A. R., Lavega, P., Lagardera, F., Aráujo, P., \& Rodrigues, M. (2014). Educando para la paz jugando: género y emociones en la práctica de juegos cooperativos competitivos. Educatio Siglo XXI, 32(1), 15-32.

21. Kivikangas, J. M., Kätsyri, J., Järvelä, S., \& Ravaja, N. (2014). Gender differences in emotional responses to cooperative and competitive game play. PloS ONE, 9(7), e100318.

22. Lagardera, F. \& Lavega, P. (2011) Educación Física, conductas motrices y emociones. Ethologie \& Praxeologie, 16(1), 23-43.

23. Larraz, A. (2004). Los dominios de acción motriz como base de los diseños curriculares en educación física: el caso de la comunidad autónoma de Aragón en educación primaria. In F. Lagardera y P. Lavega (eds.) La ciencia de la acción motriz (203-226). Lleida: Universidad de Lleida

24. Lavega, P., Alonso, J. I., Etxebeste, J., Lagardera, F., \& March, J. (2014). Relationship between traditional games and the intensity of emotions experienced by participants. Research Quarterly for Exercise and Sport, 85(4), 457-467. https://doi.org/10.1080/02701367.2014.961048

25. Lavega, P., Filella, G., Lagardera, F., Mateu, M., \& Ochoa, J. (2013). Juegos motores y emociones. Cultura y Educación, 25(3), 347-360. https://doi.org/10.1174/113564013807749731 


\section{Predictive variables of psychological orientation in the sports initiation of basketball}

26. Lavega, P., Lagardera, F., March, J., Rovira, G., \& Aráujo. P. (2014). Efecto de la cooperación motriz en la vivencia emocional positiva: perspectiva de género. Movimento, 20(2), 593-618.

27. Lavega, P., Sáez de Ocáriz, U., Lagardera, F., March-Llanes, J., \& Puig, N. (2017). Emotional experience in individual and cooperative traditional games. A gender perspective. Annals of Psychology, 33(3), 538-547. http://dx.doi.org/10.6018/analesps.33.3.260811

28. Lavega-Burgués, P., March-Llanes, J., \& MoyaHigueras, G. (2018). Validation of Games and Emotions Scale (GES-II) to study emotional motor experiences. Journal of Sport Psychology, 27(2), 117124.

29. Lazarus, R. S. (2000). How emotions influence performance in competitive sports. The Sport Psychologist, 14, 229-252. https://doi.org/10.1123/tsp.14.3.229

30. Musculus, L., Raab, M., Belling, P., \& Lobinger, B. (2018). Linking self-efficacy and decision-making processes in developing soccer players. Psychology of Sport and Exercise, 39, 72-80. https://doi.org/10.1016/j.psychsport.2018.07.008

31. Mellalieu, S., Hanton, S., \& O'Brien, M. (2004). Intensity and direction of competitive anxiety as a function of sport type and experience. Scandinavian Journal of Medicine and Science in Sports, 14, 326334. DOI:10.1111/j.1600-0838.2004.00389.x

32. Muñoz, V., Lavega, P., Serna, J., Sáez de Ocáriz, U., \& March, J. (2017). Mood states when playing alone or in cooperation: Two unequal motor and affective experiences. Revista Anales de Psicología $33(1)$, 196-203. https://doi.org/10.6018/analesps.33.1.233301

33. Ntoumanis, N. (2005). A prospective study of participation in optional school physical education using a self-determination theory framework. Journal of Educational Psychology, 97(3), 444-453. doi: 0.1037/0022-0663.97.3.444

34. Parlebas, P. (2001). Juegos, deporte y sociedad. Léxico de praxiología motriz. Barcelona: Paidotribo.

35. Pic, M. (2017). The observation of gender differences in handball. E-balonmano.com: Revista de Ciencias del Deporte 13(3), 191-198. http://www.ebalonmano.com/ojs/index.php/revista/index
36. Pic, M. (2018). Olympic Programme in Rio 2016 under Debate. Apunts: Educació Física i Esports, 132(2), 7-21. doi: doi.org/10.5672/apunts.20140983.es.(2018/2).132.01

37. Pic, M., Navarro-Adelantado, V., \& Jonsson, G. K. (2018). Detection of Ludic Patterns in Two Triadic Motor Games and Differences in Decision Complexity. Frontiers in Psychology, 8, 2259. http://dx.doi.org/10.3389/fpsyg.2017.02259

38. Prieto, J. (2017). Experiencia deportiva, ansiedad y motivación en corredores populares. Cuadernos de Psicología del Deporte, 17(1), 51-58.

39. Reina, M., Mancha, D., Feu, S., \& Ibáñez, S. J. (2017). ¿Se entrena como se compite? Análisis de la carga en baloncesto femenino. Revista de Psicología del Deporte, 26(3), 09-13.

40. Sáenz-López, P., Mateos, J. L., Almagro, B. J., \& Conde, C. (2017). Apoyo a la autonomía, creencias implícitas de habilidad y metas de logro en jugadoras de baloncesto en formación. Cuadernos de Psicología del Deporte, 17(3), 199-206.

41. Sáez de Ocáriz, U., Ureña, N., Lavega, P., \& Serna, J. (2013). Género y emociones en los futuros docentes en Educación Física. El ejemplo de las situaciones motrices de cooperación. I Congreso Internacional y II Nacional de Investigación e Innovación en educación infantil y primaria. Universidad de Murcia.

42. Sáez, U., Lavega, P., Mateu, M., \& Rovira, G. (2014). Emociones positivas y educación de la convivencia escolar. Contribución de la expresión motriz cooperativa. Revista de Investigación Educativa, 32(2), 309-326. doi: 10.6018/rie.32.2.183911

43. Ministeri d'Educació i Ensenyament Superior d'Andorra (2018). Programa d'educació física de segona ensenyança de l'Escola Andorrana. Ministeri d'Educació i Ensenyament Superior. https://www.educacio.ad/images/stories/estudis/2aEn senyanca/Prog2Ense_EdFisica.pdf

44. Serna, J., Muñoz, V., Lavega, P., March-Llanes, J., Sáez de Ocáriz, U. S., \& Hileno, R. (2017). Influencia de las tareas motrices sobre los estados de ánimo en baloncesto. Revista de Psicología del deporte, 26(1), $37-44$. 